\title{
THE RESEARCHES OF DR. MARTINUS VAN MARUM (1750-1837) ON THE INFLUENCE OF ELECTRICITY ON ANIMALS AND PLANTS ${ }^{1}$
}

by

W. D. HACKMANN

\section{INTRODUCTION}

MARTINUS VAN MARUM was born in Delft, Holland, and graduated in medicine and botany in Groningen in 1773. He moved to Haarlem, where in 1777 he was appointed Director of the 'Cabinet of Natural Curiosities' of the Hollandsche Maatschappij der Wetenschappen, ${ }^{2}$ and in 1794 he became the second secretary of this society. In 1784 he also became the Librarian of the Teyler Stichting, and the Director of its Museum. Van Marum worked in many fields, including chemistry, geology, palaeontology and botany. He is well known for his introduction of Lavoisier's new chemical system into The Netherlands, and for his experiments with Teyler's large triboelectric generator, at that time the largest in Europe. ${ }^{3}$ In 1798 he was elected a fellow of the Royal Society, and many other foreign societies also honoured him in this way. Van Marum conducted most of his electrical experiments during the years 1780 to 1790 , and, like many others, he investigated the influence of electricity on the body, as by this time a considerable amount of material existed concerning the use of electricity in medicine. This work can be directly linked to Van Marum's research on the influence of electricity on plants. Most of his results were inconsistent with those reached by his Dutch contemporaries.

EIGHTEENTH-CENTURY IDEAS ON THE INFLUENCE OF ELECTRICITY ON THE BODY

The idea that there existed in the body an electric fluid in continual motion was based on observations and experiments in many different fields. One of these was atmospheric electricity. Experiments with the 'electrical kites' and devices for measuring atmospheric electricity had shown that the amount of electric fluid in the air was constantly changing. These variations had a great influence on the amount of electric fluid on all objects in contact with it, for the electric fluid on the earth and in the surrounding atmosphere was at all times trying to reach an electrical equilibrium. It was not simply the general circulation of electric fluid which caused these variations,

${ }^{1}$ On Van Marum see R. J. Forbes, (ed.), Martinus van Marum Life and Work, Haarlem, Tjeenk Willink en Zoon, 1969-. Three volumes have so far been published. A photograph of Van Marum appears as the frontispiece to vol. I. In this paper I have not discussed the work of Luigi Galvani (1737-1798) on animal electricity (1791), as this had no bearing on Van Marum's work on medical electricity, but only on his work on the voltaic pile in 1800 . See my chapter in Forbes, ibid., iii, 1971, pp. 329-78, dealing with Van Marum's electrical theory.

2 A good short history of this society can be found in J. A. Bierens de Haan, De Hollandsche Maatschappij der Wetenschappen 1752-1952, Haarlem, Holl. Maat. Wetensch., Haarlem, 1952. This work contains a useful English summary.

'B. Dibner, 'The Great Van Marum Electrical Machine', The Nat. Phil., 1963, 2, 67-103, and his Early Electrical Machines, Norwalk, Conn., (Burndy Library, 1957), pp. 43-49. W. D. Hackmann, 'The design of the triboelectric generators of Martinus van Marum, F.R.S. A case history of the interaction between England and Holland in the field of instrument design in the eighteenth century,' Notes Rec. $\boldsymbol{R}$. Soc. Lond., in press. 


\section{W. D. Hackmann}

but also specific local natural phenomena. Thus, rain deposited electric fluid on to the ground, plants, and animals on which it fell, and electrified clouds, moving overhead, affected the electrical balance of all the objects over which they floated by pushing some of the natural amount of the electric fluid contained in these objects out of them and into the earth. ${ }^{4}$ These observations on atmospheric electricity led to the general conclusion that the continual movement of the electric fluid between the atmosphere and the earth meant that the electric fluid in the animal body, too, was in continual motion. ${ }^{5}$

Many scholars thought that the electric fluid in the animal body was also brought into a continual motion by the action of the body itself. Thus, a certain amount of electric fluid was produced by the circulating blood rubbing against the walls of the blood vessels, and this friction was also the cause of the warmth or 'animal heat' of the body as it set free 'elementary fire'. Priestley, in his Experiments and Observations on Different Kinds of Air of 1774, and other scholars, tried to prove the similarity between the 'elementary fire' or phlogiston and the electric fluid, and that the circulation of blood not only produced phlogiston but also electric fluid. ${ }^{6} \mathrm{He}$ thought that it was because of the large amount of electric fluid produced in certain animals such as cats and tigers when they were highly aroused (i.e. when frightened or about to pounce on their prey) that they gave off light." Some believed that exercising the body also affected the amount of electric fluid contained in it, for the friction of the limbs against particles of air produced electric fluid. ${ }^{8}$ Mauduit on the other hand, wrote in the Mémoires de la Société Royale de Médecine of 1777 and 1778 that during perspiration the body lost a certain amount of electric fluid. ${ }^{9}$ Many of these theories were current, some rather ridiculous, but they all agreed that electric fluid had a great influence on the body. In L'Esprit des Journeaux of 1783, for instance, it was stated that drunk men were always positively charged, since the alcohol they imbibed contained electric fluid. The Dutch apothecary W. Van Barneveld (1747-1826), a pharmacist in Amsterdam, considered that if this were the case, the drunkard could again be made sober by electrifying him negatively, and this obviously was not the case $!^{10}$ Neither did he believe that a person electrified with a charged Leyden jar filled with

- J. R. Deiman and P. van Troostwijk, 'Verhandeling over de geneeskunstige electriciteit', Verh. proefonderv. Wijsbeg., 1787, 8, 70-73, 83. Johan Rudolph Deiman (1743-1808) graduated in medicine in 1770, took up a practice in Amsterdam, and in his spare time studied chemistry and philosophy. He was very interested in the medical applications of electricity. With Van Troostwijk he was one of the unofficial group known as the 'Dutch Chemists', famed for their work on 'pneumatic chemistry', especially for their experiment on the electrolysis and synthesis of water performed in 1789 . He assisted Van Marum with many of his early electro-chemical experiments.

Adriaan Paets van Troostwijk (1752-1837), merchant and an extremely proficient experimenter in chemistry, who assisted Van Marum with many of his electro-chemical experiments, and also with his eudiometric determinations. In 1797 he wrote an important work on the history of chemistry.

s Ibid., p. 81.

- J. Priestley, Experiments and Observations on Djfferent Kinds of Air, 3 vols., London, 1774-1777, i, part II, section II, p. 192; section VIII, pp. $274-80$.

Ibid., i, section VIII, p. 279 . Deiman and Van Troostwijk, op. cit., pp. $89 \mathrm{f}$.

8 Deiman and Van Troostwijk, op. cit., pp. 87f.

- Antoine René Mauduit (1731-1815), professor of mathematics at the École des Ponts et Chaussées. His name is sometimes written as Manduit, Maduit or Mauduyt. The articles referred to are his 'Sur le traitement électrique, administré à quatre-vingt-deux malades', Histoire et Mémoires de la Société Royale de Médécine, 1777-1778, ii, 199-432, and 'Sur les effets generaux, la nature et l'usage du fluide électrique, considéré comme médicament', ibid., pp. 432-55.

10 W. van Barneveld, Geneeskundige electriciteit, 3 vols., Amsterdam, 1785-1789, i, pp. $56 f$. 
spices would take on the aroma of these spices and so be cured by their purgative action. ${ }^{11}$

There certainly was a great deal of controversy about the effect of the electric fluid on the body. Some believed that the continual variations of the electric fluid in the body caused by changes in atmospheric electricity would have an effect on the working of the body. Others believed that this had no effect, since electricians who had long performed electrical experiments did not become ill. Thus, Deiman in 1787 thought that the electric matter only influenced the body when it could no longer pass freely through its pores and was therefore either accumulated in the body, or was trapped outside causing an electrical deficiency. ${ }^{12}$ It was for this reason that certain phenomena, such as increases in the pulse rate and the rate of perspiration, took place in the body when it was insulated and artificially electrified. He agreed here with Musschenbroek, ${ }^{13}$ Nollet, ${ }^{14}$ Jallabert, ${ }^{15}$ Mauduit, ${ }^{16}$ Sauvages, ${ }^{17}$ and many others.

In the eighteenth century, the greatest influence electricity was considered to have on the body was on its nervous system. In The Netherlands, Van Barneveld agreed with Ypey's idea in his prize essay published in the proceedings of the Batavian Society that the nervous system was the seat of the 'principium vitale', and that the electric matter, by stimulating the nerves, also stimulated the principle of life. Boerhaave had seen the nerves as hollow tubes through which flowed a liquid which transmitted the orders of the soul to the body. ${ }^{18}$ Van Barneveld did not know whether such a liquid existed, but thought there was a great affinity between the nerves and electricity. ${ }^{19}$ First of all, there was a great similarity between the speed with which electricity travelled and the speed of the action of the nerves. In the latter case, the orders given by the soul via the nerves were carried out by the muscles with no appreciable time-lag. Haller had calculated that the nervous fluid travelled with a speed of $9,000 \mathrm{ft}$. per second, and the speed of the electric matter was even faster. ${ }^{20}$

${ }^{12}$ There were many of these curious theories in circulation at this time. See Park Benjamin, The Intellectual Rise in Electricity, London, 1895, pp. 502-5.

12 Deiman and Van Troostwijk, op. cit., pp. $91 \mathrm{f}$.

13 P. van Musschenbroek, Introductio ad philosophiam naturalem, 2 vols., Leiden, 1762, i, p. 378.

P. van Musschenbroek (1692-1761), professor of experimental philosophy at Utrecht from 1723 and Leiden from 1740. The Musschenbroek family were renowned instrument makers. See M. Rooseboom, Bijdrage tot de geschiedenis der instrumentmakerskunst in de Noordelijke Nederlanden tot omstreeks 1840, Leiden, Rijksmuseum voor de Geschiedenis der Natuurwetenschappen, 1950, pp. 102-9.

i1 J. A. Nollet, Recherches sur les causes particulières des phénoménes électriques, Paris, 1749, p. 366.

Abbé Jean Nollet (1700-1770), French physicist, naturalist and popularizer of science. His Expériences sur l'électricité, Paris, 1748, was an extremely popular textbook in Holland and was used by Van Marum.

${ }_{16}$ Jean Louis Jallabert (1712-1768), professor of philosophy and mathematics at Geneva who repeated many of the experiments of Dr. Watson and Nollet, and who also investigated the use of electricity as a therapeutic agent. D. W. Hutchings, 'Physical science in Geneva during the eighteenth century (1740-1790)', unpublished M.Sc. thesis, University College, London, 1960. According to Colwell, Jallabert was the first scientific electrotherapist. In 1747 he noticed the contraction of muscles when subjected to an electric discharge. See Hector A. Colwell, An Essay on the History of Electrotherapy and diagnosis, London, Heinemann, 1922, pp. 19-21, 30.

16 A. R. Mauduit, op. cit., p. 432.

${ }^{17}$ F. Boissier de Sauvages (1706-1767), French physician and botanist. Deiman and Van Troostwijk, op. cit., pp. 103ff, gives many references from the literature of the period.

${ }_{18}$ For Boerhaave's theory on nerves, see Van Barneveld, op. cit., i, p. 93, and A. Ypey, 'Verhandeling over het lichamelijk levensbeginsel', Verh. preofonderv. Wijsbeg., 1786, 1, 71.

Adriaan Ypey (1749-1820), Dutch physiologist and physician.

10 Van Barneveld, op. cit., i, passim.

20 Albrecht von Haller (1708-1777), Swiss physiologist. His work is fully discussed in C. H. Wilkinson, Elements of Galvanism in Theory and Practice, 2 vols., London, 1804, ii, pp. 361-65. 


\section{W. D. Hackmann}

Nerves gave the body the sense of feeling, and electric matter caused irritation in the healthy body but not in parts which were paralysed, for these had no sense of feeling. He therefore wondered whether there was not a specific relationship between electricity and nerves, for in the dead body the soul, or the 'principium vitale' had gone, and electricity, too, could cause no irritability. Nerves, as conductors of electricity, were almost as good as metals, but Van Barneveld did not know whether they had, in fact, electrical properties or were only electrical in action. Some scholars did make the latter assertion, and they were strengthened in their belief by the discovery of the electrical properties of the torpedo fish. ${ }^{21}$ Van Barneveld, however, preferred to keep an open mind about this question, but since electricity did have an influence on the living body, could it also not be used for medicinal purposes? According to him, it did not matter if we could not understand how it worked, for after all many of the medicines in daily use worked without the doctors knowing how they acted on the affected part of the body. ${ }^{22}$ Most physicians agreed that electricity could be used as a curing agent in the following four types of illnesses: ${ }^{23}$ (1) those caused by paralysis; (2) those caused by the irregular working of the principle of life; (3) those caused by bad circulation of the fluids in the body; and (4) those caused by the prevention of the perspiration of body fluids.

In The Netherlands, the first comprehensive survey on medical electricity was written by Deiman in 1779. ${ }^{24}$ As a physician, he was, of course, very interested in this topic. This work was in reality a collection of case histories of patients treated by electricity. Deiman's first intention had been to translate J. F. Hartmann's Die angewandte Electricität bei Krankheiten des menschlichen Körpers, published in Hannover in 1770, but he disagreed with the order in which these case histories had been presented, and also discovered some important omissions. This made him decide to write his own book. Many of the cases he mentioned were taken from English sources. ${ }^{25} \mathrm{He}$ also mentioned cures by the German physician Kratzenstein, who in 1744 was the first to use electricity for medicinal purposes, ${ }^{26}$ and many others, including the Reverend John Wesley, the founder of methodism. ${ }^{27}$ The illnesses

21 Van Barneveld, op. cit., i, p. 72. H. Cavendish, 'An account to imitate the effects of the torpedo by electricity', Phil. Trans. R. SSoc. Lond., 1776, 46, 196-225.

"2 Van Barneveld, op. cit., i, pp. 60-62.

Deiman and Van Troostwijk, op. cit., pp. 149-53.

4 J. R. Deiman, Geneeskundige proeven en waarnemingem omtrent de goede uitwerking der electriciteit, Amsterdam, 1779.

${ }^{25}$ These sources are to be found in J. Priestley, The History and Present State of Electricity, London, 1767 , Section XIV, pp. 408-22. For those interested in the history of medical electricity, this is a good starting point.

is C. G. Kratzenstein (1723-1795) appears to have been the first to use electricity for medical purposes; see his Abhandlung über dem Nutzen Elektricität in der Arzneiwisschaft, 2nd ed., Halle, 1745, pp. 10-14, and also J. Fisher, 'A general history of electricity during the first half of the Eighteenth Century with special reference to the German workers', unpublished M.Sc. thesis, University College London, 1956.

" Deiman, op. cit., pp. 49, 125, 174. See also P. F. Mottelay, Bibliographical History of Electricity and Magnetism, London, Charles Griffin, 1922, p. 216.

The Rev. J. Wesley (1703-1791) had a great faith in the therapeutic powers of electricity and wrote a popular eighteenth-century book on this topic, The Desiridatum: or, Electricity made Plain and Useful. By a Lover of Mankind, and of Common Sense, London, 1760. For an interesting excerpt from this work, see R. Hunter and Ida Macalpine, (eds.), Three Hundred Years of Psychiatry 1535-1860. A History Presented in Selected English Texts, London, Oxford University Press, 1963, pp.420-24. 
ranged from depression, epilepsy, paralysis, convulsions and hysterical attacks, to tapeworms, blindness, and toothaches. In The Netherlands, too, many physicians were using electricity as a curative agent, two of the most prominent being De Haan, ${ }^{28}$ and Professor Bonn. ${ }^{29}$ Other Dutch works written by Deiman and Paets van Troostwijk in 1787, and by Van Barneveld in 1789 soon followed. Van Barneveld's work was the most comprehensive, giving not only his theory documented by references to other scholars, but also many of his own treatments described in great detail. Van Krayenhoff also wrote on this topic in $1788 .^{30}$ Deiman, Paets van Troostwijk, Van Barneveld, and Cuthbertson, all believed that electricity influenced such body functions as the circulation of the blood and the perspiration of body fluids, and all conducted experiments to prove this. Van Barneveld, just before the publication of his 1789 work, travelled to Haarlem, and was electrified by Cuthbertson using Teyler's large electrical machine consisting of two glass plates 65 inches in diameter. $^{31}$ In the first electrification his pulse-rate increased from 80 to 84 beats per minute, and in the second experiment from 80 to 95 per minute. ${ }^{32}$ Van Marum made no reference to this experiment when discussing his own investigations on the pulse.

\section{FORMS OF TREATMENT}

In England, the triboelectric generator used in treatment would be the glass cyclinder machine, and, in fact, in 1782, the English instrumentmaker Edward Nairne patented his 'Insulated Medical Electrical Machine' specifically for this purpose. ${ }^{33}$ In Holland, the glass disc or plate machine was more generally used. Hence, Van Barneveld in 1789 recommended the plate machines constructed by Cuthbertson, even though in 1784 he had seen a Nairne machine in operation at a friend's house. ${ }^{34}$ The amount of high potential charge generated depended on the size of the prime conductor or the Leyden jar accumulating the generated charge. The shocks could

\footnotetext{
${ }^{28}$ Deiman, op. cit., passim. Most of these case histories are obtained from Dr. A. de Haan, Ratio Medendi in Nosocomio Practico, Vienna, 1757-1774, 17 vols. Anthony de Haan (or Haen) (17041776), Aulic Counsellor and Physician to the Empress Maria Theresa, and professor of medicine at Vienna.

${ }^{20}$ A. Bonn (1738-1817), professor of anatomy and medicine in Amsterdam. In the particular treatment referred to in Deiman, op. cit., pp. 41-46, Bonn was assisted by Cuthbertson. He is also mentioned in Van Barneveld, op. cit., i, p. 209.

${ }^{30}$ C. R. T. van Krayenhoff and P. van Troostwijk, De l'Application de l'Électricité à la Physique et d̀ la Médécine, Amsterdam, 1788.

Cornelius Rudolphus Theodorus Baron van Krayenhoff (1758-1840), doctor, patriot and general who was very interested in the practical application of electricity. In 1782, while still studying in Harderwijk, he fitted the Doesburg church tower with a lightning conductor; the first on a public building in Holland. He also wrote several monographs on this topic. In 1783 he translated Abbé Jacquet, Essai sur l'électricité into Dutch, adding his own observations in several appendices. See G. C. Gerrits, Grote Nederlanders bjj de opbouw der natuurwetenschappen, Leiden, 1948, pp. 243-48.

${ }^{21}$ See the references in note 3 and also Van Marum's own description in 'Beschrijving eener ongemeen groote electrizeer-machine, geplaatst in Teyler's Museum te Haarlem, en van de proefneemingen met dezelve in 't werk gesteld', Verh. Teyler's Genoot., 1785, 3, 2-27. This journal is both in Dutch and in French. For a full bibliography on this machine, see J. G. de Bruijn, 'Van Marum bibliography', chapter V, in Forbes, op. cit., i, pp. 289-91.

$\$ 2$ Van Barneveld, op. cit., pp. 82f.

33 E. Nairne, The Description and Use of Nairne's Patent Electrical Machine; with the Addition of some Philosophical Experiments and Medical Observations, London, 1783.

Edward Nairne (1726-1806), English mathematical instrumentmaker, who wrote on general electrical topics including on the lightning conductor and the electrical machine.

ss Van Barneveld, op. cit., i, p. 13.
} 


\section{W. D. Hackmann}

also be controlled by the discharging electrometer invented by Lane in $1767 .{ }^{35}$ The one shown on the table in Plate II, fig. 1, is Cuthbertson's modification of this electrometer as illustrated in the second volume of his Algemene eigenschappen van de electriciteit, published in $1776 .^{36}$ Each spark jumping between the two electrodes set at a fixed distance consisted of the same quantity of electricity, and hence the strength of the shock administered to the patient could be regulated by varying the separation of these two electrodes. The treatment itself was extremely simple. ${ }^{37}$ As can be seen in Plate $I$, the patient is placed in an insulating chair $E$ and is connected to the prime conductor B of the electrical machine by means of a stout copper wire or chain C. Incidentally, the generator depicted here is of the type made by Cuthbertson. In this case, the patient is electrified positively, and is, in the language of the period, surrounded by a positive electrical atmosphere $\mathrm{H}$. He can also be electrified negatively after a few slight modifications to the arrangement of the apparatus. The patient, surrounded in this way by an electrical atmosphere, was said to be given an 'electric bath'. The extent of this electrical atmosphere was measured by the pithball electroscopes 1, K. According to Van Barneveld, this treatment should be administered daily for one hour. During the electrification process sparks could be drawn from the patient by means of the earthed copper spheres (Plate II, H and I), and the strength of the spark or shock could, to some extent, be regulated by the size of these spheres. An increase in size would mean an increase in shock. Plate III shows another form of treatment. In this case, the part of the body undergoing treatment forms part of the electric circuit. The charge enters the body via the wire $c$ and leaves it at $d$. The amount of charge entering the body is controlled by the discharging electrometer $a$ to which wire $c$ is connected, while $d$ is earthed. There existed a multitude of minor variations in treatment on this general theme, but these do not concern us here.

\section{VAN MARUM'S RESEARCHES}

Van Marum investigated three of the main aspects of medical electricity on which most of the medico-electrical theories were based. He performed experiments on the influence of electricity on the circulation of the blood, on the irritability (irritabiliteit) of animals and plants, and on the effect it had on the rate of perspiration (uitwaasseming) of animals and evaporation (uitwaaseming) of plants. ${ }^{38}$ The experimental results he obtained on the pulse rate and the rate of perspiration of animals and evaporation of plants were totally contrary to those obtained by his Dutch contemporaries, for Van Marum found that these were not affected by electrification. On the other hand, his experiments demonstrating that both the irritability of animals and of plants were destroyed by electricity, were in agreement with his contem-

\footnotetext{
${ }^{85}$ Ibid., p. 41. T. Lane, 'Description of an electrometer invented by Mr. Lane, with an account of some experiments made by him,' Phil. Trans. R. Soc. Lond., 1767, 57, 451-60.

${ }^{36} \mathrm{~J}$. Cuthbertson, Algemeene eigenschappen van de electriciteit, onderrichting van de werktuigen in het neemen van proeven in dezelve, 2 vols., 2 nd ed., Amsterdam, 1782, ii, Pl. I, fig. 15, and described on pp. 6f. John Cuthbertson (1745-c. 1822), English instrumentmaker who settled in Amsterdam from 1768 to $c$. 1799. He constructed Teyler's large electrical machine and had a great influence on the design of the disc frictional machine in Holland. He is often confused with another English instrumentmaker, Jonathan Cuthbertson, who lived in Rotterdam.

${ }^{37}$ Van Barneveld, op. cit., i, pp. 24-48.

sa Van Marum. op. cit., p. 99.
} 
poraries. This research became well known, and he received much praise for it, especially from foreign scholars.

\section{EXPERIMENTS ON THE PULSE RATE}

According to Van Marum in the 1785 volume of the Verhandelingen, uitgegeeven door Teyler's Tweede Genootschap, there was a tremendous diversity of opinion in the literature dealing with the influence of the electrical current on the pulse rate, i.e. on the speed of the circulation of the blood. ${ }^{39}$ Some, like Gerhard of Berlin, noticed a great increase in the pulse rate of the electrified person, ${ }^{40}$ while others observed no increase whatsoever. Yet others believed that a positive charge increased the pulse rate while a negative one decreased it. Tiberius Cavallo, on the other hand, observed that both positive and negative electrifications increased the pulse rate by about one sixth. ${ }^{41}$ Van Marum considered that it would be worthwhile investigating these observations using Teyler's large electrical machine. He was sure that its great electrical power would bring this study to a satisfactory conclusion. ${ }^{42}$

Van Marum ordered Cuthbertson to construct a large insulating table with four glass legs, each one $31 \frac{1}{2}$ inches long. ${ }^{43}$ This table could support three persons at any one time, so that both the person to be electrified, and those checking his pulse, could be insulated at the same time. He first checked his own pulse by sitting down on this table, connecting himself by means of a long copper chain to the prime conductor, and while the electrical machine was in motion, counting his own pulse for one minute at a time. He repeated this operation several times, but on no occasion noticed any difference in his pulse rate before and after electrification, except for the occasional very small differences which he associated with slight irregularities in the pulse rate. ${ }^{44}$ He repeated this experiment on several occasions on other people, but he always obtained the same result. This he found rather surprising, since his experimental result was contrary to the generally accepted opinion that electrification did influence the pulse rate and the circulation of the blood. It was on this assumption that the generally held belief was based that the continual variation of the quantity of electric matter found in the atmosphere had a great influence on certain body functions. Thus, Van Marum's experimental result was not only contrary to a generally held theory, but also to a vast amount of experimental data collected on this topic. He decided to continue his investigation. To make it more decisive, he requested the assistance of Cuthbertson, Deiman and Paets van Troostwijk, as these three were accustomed to experiments with electricity, and whose pulse rate would therefore not be affected by fear while they were being electrified. They arrived on 14 May

so Ibid., pp. 97-111.

40 Ibid., p.97. Van Marum is here most probably referring to K. A. Gerhard (1738-1821), physician and medical writer.

¿T. Cavallo, Essay on the Theory and Practice of Medical Electricity, London, 1780, p. 13.

Tiberius Cavallo (1749-1809), an Italian who settled in London as an instrumentmaker and was a member of the Chapter Coffee House and later Baptist Head Coffee House Society, see Gunther MSS 4 in the Museum of the History of Science, Oxford. Cavallo also wrote on gases and experimented with thermometers.

\& Van Marum, op. cit., p. 99.

is M. van Marum, Journal van mijne verrichtingen ter verkrijging eener verzameling van physische instrumenten, entry of 25 December 1785, item V. This manuscript is numbered in De Bruijn's bibliography as MS 17 (b). See Forbes, op. cit,. i, p. 320.

« Van Marum, op. cit., (n. 31), p. 101. 


\section{W. D. Hackmann}

1785. ${ }^{45}$ The procedure was as before. Two observers (usually Deiman and Van Marum) climbed onto the insulating table with the person to be electrified. They counted the subject's pulse for one minute, waited for half a minute while the electrical machine went into action, then counted his pulse for another minute while he was being charged, waited for another half a minute, and then recounted his pulse for another minute. No counts were recorded unless both observers counted the same number during the experiment. Each person was electrified positively in the morning and negatively in the afternoon, and Van Marum thought that it was because of this rather long time lapse that there was a slight difference between the morning and afternoon pulse rates. In fact, the afternoon pulse rates tended consistently to be slightly higher. Even so, this did not detract from the general conclusion that there was no difference between the pulse rate of the subjects before and after electrification. ${ }^{\mathbf{4 6}}$

Van Marum next requested the assistance of two well-known local physicians, Bartholomeus Tersier and Willem Brouwer Bosch, and also several members of the Teyler Foundation, and he repeated the above experiments. This time his subjects included people of both sexes, and were of a wide age range, but his experimental results remained the same; the electrical current did not influence the pulse rate. ${ }^{47}$

One feels that Van Marum was quite satisfied with the above conclusion, but in his 1795 volume of the Verhandelingen, uitgegeeven door Teyler's Tweede Genootschap he returned to this topic, and described a similar experiment performed in $1790 .{ }^{48} \mathrm{He}$ had hoped that his experimental results obtained 1785 would have been generally accepted, especially as in about half the experiments he had been assisted by three people who shortly before had asserted that the pulse was influenced by the electrical current. Van Marum was here, of course, referring to the work of Cuthbertson, Deiman and Paets van Troostwijk. ${ }^{49} \mathrm{He}$ argued that these investigators would only have accepted his totally opposite conclusion (that the pulse was not affected by the electrical current) after the most strenuous investigation. However, many scholars were still sceptical of his results, and argued that he had not used enough subjects. An additional complication was that a paper appeared in 1787 written by Deiman and Paets van Troostwijk for the Verhandelingen van het Bataafsch Genootschap der Proefondervindelijke Wijsbegeerte ${ }^{50}$ in which they related an experiment having the appearance of great accuracy and which claimed to prove that the pulse rate was increased during electrification. In fact, this experiment was quite an ingenious one. The authors placed in a separate room, in which even the noise of the electrical machine turned in another room could not be heard, two subjects skilled in taking pulses. They were insulated and connected to the electrical machine by means of a long copper wire. They were told to take each other's pulse for a certain length of time and these were recorded by a third person. In the other room, the electrical machine was turned at irregular intervals and these were also

${ }^{45}$ Ibid., p. 103, and his laboratory journal entitled, Journaal van proefnemingen met Teyler's electrizeer-machine 1784-1789, pp. 27-29, and many more entries dealing with his medical experiments. Numbered by De Bruijn as MS 13-9 in Forbes, op. cit., i, p. 317.

¿Van Marum, op. cit., (n. 31), p. 107.

${ }^{47}$ Ibid., p. 109.

68 M. van Marum, 'Tweede vervolg der proefneemingen gedaan met Teyler's electrizeer-machine', Verh. Teyler's Genoot., 1795, 9, 51-63.

40 Cuthbertson, op. cit., i, pp. 10f. For the other see notes 4, 24, and 30.

${ }^{\text {so }}$ See note 4. 
recorded. When comparing the times when the electrical machine was in motion with the records of the pulse rates, the authors considered that the influence of the electrical current on the pulse was confirmed beyond doubt.

However, the authors had conducted their experiment in 1783, two years before their experiments with Van Marum, but their paper was not published until 1787. Since this delay was not recorded in the published paper, Van Marum felt that this account gave the impression that Deiman and Paets van Troostwijk had repudiated the results they had obtained with Teyler's large machine in 1785 . It was this consideration which made Van Marum decide to repeat his experiments on the pulse. He asked the assistance of N. C. de Fremery, author of Dissertatio fulmine, 1790, and J. Kraglingh, who was a local physician. This time he used many more subjects, all of whom were accustomed to experiments with electricity, and who were therefore not frightened of being electrified. As he expected, he reached exactly the same conclusion as before; the electric current had no noticeable influence on the pulse. ${ }^{51}$

\section{EXPERIMENTS ON THE RATE OF PERSPIRATION}

The next question which Van Marum tackled was to see whether electrification had any influence on the rate of the invisible perspiration (onzichtbaare uitwaasseming) of the body. This was generally held to be the case. According to Van Marum, this belief was primarily based on the observations of 'medico-physicians'52 and others, that patients would sweat profusely while they were being charged, or during the administration of electrical shocks. Van Marum constructed a large and very sensitive balance, one of the pans of which was suspended by means of silk cords that at the same time insulated it. In it he placed an 8-year-old boy, weighed him, and then, before starting his experiment, observed the amount of weight he lost due to perspiration in half an hour. This weight loss amounted to 180 grains. He next electrified him for half an hour, and found that at the end of that time he had lost a further 195 grains. He repeated this experiment on another day on the same boy, and then asked De Fremery to assist him in a further series of experiments, the results of which can be tabulated as Table 1, p. 20.

Van Marum considered that the large difference in the amount of perspiration of the $8 \frac{1}{2}$-year-old boy before and after electrification was due to fear, but that of the 9-year-old boy was more difficult to explain since he had shown no signs of fear at the start of the experiment. Perhaps, in this case, it was indeed caused by the electrification process. However, on repeating this experiment on the same boy on another day, he lost 550 grains before and only 390 grains after electrification. Van Marum wondered whether this difference had not been caused by the change of temperature, for the hall in which the experiments were conducted was considerably cooler on this particular day than the temperature outside. Hence the boy would have become cooler during the course of the experiment. He repeated this experiment twice more, and before the start of the last one, he made the boy stand in the hall

s1 Van Marum, op. cit., (n. 48), pp. 61-63.

52 This term was, in fact, not used by Van Marum. I have taken it from a pamphlet on medical electricity written by Dudley Adams advocating his method of treatment, entitled, Electricity is the fountain, the great vivifying principle of nature; a source of life and health: medicine the requisite accessory to that science, London, 1820, 15 pp. 


\section{W. D. Hackmann}

for one and half hours so that he would become thoroughly acclimatized. Van Marum concluded that this whole series of experiments seemed to point rather to a decrease in perspiration during electrification, for only twice had he obtained an actual increase. The differences in perspiration obtained here before and after electrification however, were no larger than the variations obtained in an unelectrified person. ${ }^{53}$ One wonders why Van Marum here did not refer to his experiment on the evaporation of liquids in porcelain dishes when he discovered that electrification did not increase their evaporation. This experiment, suggested to him by Volta, ${ }^{54}$ was one of a series attempting to test the hypothesis that cloud formation was electrical in nature. Van Marum could have used this experimental result as an additional proof that perspiration, or the evaporation of the bodily fluids, was not influenced by electrification. ${ }^{55}$

Table 1

\begin{tabular}{|c|c|c|c|c|c|}
\hline No. & Day & Subject & Weight & $\begin{array}{l}\text { Weight-loss due to } \\
\text { perspiration after } \\
\text { half an hour }\end{array}$ & $\begin{array}{c}\text { Weight-loss due to } \\
\text { perspiration after } \\
\text { half an hour whilst } \\
\text { electrified }\end{array}$ \\
\hline 1 & 1 & 8-year-old boy & not given & 280 grains & 295 grains \\
\hline 2 & 2 & 8-year-old boy & not given & 330 grains & 310 grains \\
\hline 3 & & (6-year-old girl & $49 \mathrm{lbs}$ & 180 grains & 165 grains \\
\hline 4 & $3-$ & $8 \frac{1}{2}$-year-old boy & $57 \mathrm{lbs}$ & 430 grains & 290 grains \\
\hline 5 & & 9-year old boy & $53 \mathrm{lbs}$ & 170 grains & 240 grains \\
\hline 6 & & (9-year-old boy & $53 \mathrm{lbs}$ & 550 grains & 390 grains \\
\hline 7 & 4 & 9-year-old boy & $53 \mathrm{lbs}$ & 300 grains & 270 grains \\
\hline 8 & & 9-year-old boy & $53 \mathrm{lbs}$ & 530 grains & 420 grains \\
\hline
\end{tabular}

s8 Van Marum, op. cit., (n. 48), pp. 62-67.

st J. Bosscha, La correspondence de A. Volta et M. van Marum, Leiden, 1905. Many of Volta's letters to Van Marum deal with his ideas on atmospheric electricity, but see especially Volta's letters, XI of 23 July 1789, pp. 46-51, and XII of 28 March 1792, pp. 54-58. The experiments referred to here are to be found in Van Marum's letter to Volta, IX of 31 August 1788, pp. 36-42, suggested to him by Volta in letter III of 8 March 1786, pp. 11-15. These experiments can also be found in Van Marum, op. cit., (n. 48), pp. 171f., and in 'A short view of the new electric experiments performed by Dr. Van Marum', Phil. Mag., 1800, 8, $314 \mathrm{f}$. Incidentally, Volta was very interested in Van Marum's medicoelectrical experiments and had little faith in the therapeutic powers of electricity: 'et vous avez fini de détruire la Phanatisme qui regne là-dessus chez plusieurs Médecins et Physiciens', letter VII, 25 June 1786, pp. $26 f$.

${ }^{65}$ Van Marum, op. cit., (n. 48), p. 69. 


\section{EXPERIMENTS ON ANIMAL IRRITABILITY}

On 8 April 1790 an editorial appeared in the Algemeene Konst- en Letterbode describing Van Marum's new battery of 550 sq. $\mathrm{ft}$. of coated glass, and also his experiments in which he tried to discover the cause of the death of animals and men struck by lightning. ${ }^{56} \mathrm{~A}$ more detailed account of these experiments appeared in the 1795 volume of the Verhandelingen, uitgegeeven door Teyler's Tweede Genootschap. Van Marum had been waiting for several years, but it was only after the construction of his 550 sq. $\mathrm{ft}$. battery that he considered that he had enough electrical power for these experiments. ${ }^{57}$

Van Marum thought that in the case of animals struck by lightning, death was most probably caused by the immediate destruction of the irritability of the animal's muscle fibres through which the lightning discharge had been conducted. As far as he knew no one had ever tried to establish this theory experimentally. It was true that many scholars had thought that the parts of the animal through which the lightning discharge passed became paralysed. However, according to Van Marum, this paralysis could be brought about by a variety of totally different causes, and no one, as far as he knew, had investigated whether the irritability of these paralysed parts had been destroyed by the lightning discharge, or whether some other cause was at work. The hypothesis put forward by some that the irritability was immediately destroyed by the lightning discharge was not supported by their experimental results. Indeed, their results made this hypothesis less probable, for generally the animals they killed by electricity were not killed instantaneously, as was usually the case with lightning. Normally, a discharge from a battery caused tremendous convulsions, which, in some cases, after a few seconds terminated in the death of the animal, but in others only caused a general paralysis from which the animal recovered within a short period of time.

Van Marum decided to experiment on the eel which belonged to the 'amphibia' whose irritability was especially difficult to destroy. ${ }^{58}$ Snakes, adders, and eels whose heads were cut off still moved for between two and four hours, and in one case he still found a certain amount of irritability in an eel's tail six hours after its head had been removed. ${ }^{59}$ In his first experiment Van Marum took an eel $1 \frac{1}{2} \mathrm{ft}$. long and made

${ }^{56}$ Editorial, 'Verslag van proefnemingen door Van Marum genomen om aan te tonen "welke de oorzaak is van de dood van menschen en dieren, die door den bliksem getroffen worden",' Alg. Konsten Letterbode, 1790, 4, 114a-115a.

${ }_{57}$ Van Marum, op. cit., (n. 48), pp. $62-67$.

s8 Van Marum was not the only one to distinguish between the irritability of the warm-blooded (his 'quadrupeds') and cold-blooded (his 'amphibia') animals. Thus, Wilkinson, op. cit., ii, pp. 191193, refers to Baron B. A. Richerand who in his work The Elements of Physiology, London, 1803, mentioned certain facts communicated to him by Pfaff to 'show the relation which subsists between galvanic susceptibility and muscular irritability ... shows that the former is extinguished in warmblooded animals, in proportion as the vital heat is dissipated; and that it is more durable in coldblooded animals'. A. von Humboldt thought in 1793 that the irritability of a body was caused by the influence of oxygen on the muscle fibres. This theory was strongly opposed by Pfaff who thought that it was of a purely electrical origin. Ibid., pp. 326-40. Van Marum did not get involved in this controversy. He was only interested in proving that electricity affected the muscle fibres. Christian Heinrich Pfaff (1772-1852), professor of chemistry at Kiel university. In 1801 he assisted Van Marum with his experiments on the voltaic pile at the request of Volta.

Friedrich Heinrich Alex von Humboldt (1769-1859), German naturalist and traveller.

Balthasar Anthelme Richerand (1779-1840), French surgeon. His French work on physiology was translated into English by Robert Kerrison, a member of the Royal College of Surgeons, London.

so Van Marum, op. cit., (n. 48), p. 229. 


\section{W. D. Hackmann}

a powerful discharge from his battery enter its head and pass out of its tail, after which it lay motionless on the table. He immediately skinned it, and by means of various stimuli tried to see whether the animal still showed any signs of irritability. Pricking it with steel points, sprinkling it with common salt and then with ammonium chloride had no results, and even giving it small shocks, which according to Van Marum were the most powerful stimuli he knew, did not make the animal move or show signs of the least irritability. He repeated this experiment with several other eels, but he always obtained the same results; not the least sign of irritability seemed to have remained in the animal killed by a powerful discharge. This experiment made Van Marum wonder whether this loss of irritability in the eel's muscle fibres was caused by the immediate destruction of these fibres, or of other parts of the eel on which its life depended. To determine this he next conducted a series of experiments with eels in which only a part of their body was included in the electrical circuit, and he found that the destruction of irritability was confined to that part through which the discharge had passed. ${ }^{\circ 0}$

When these experiments became known, presumably because of the incomplete report published in the Algemeene Konst- en Letterbode of 1790, several scientists asked him to show these experiments to them. He therefore repeated them many times, but never obtained any different results. He concluded that if an electrical current could destroy the irritability of muscle fibres in species which were known to have an irritability which was only destroyed with difficulty, there was no reason to doubt that the same current would destroy with ease the irritability of quadrupeds. The muscle fibres of the quadrupeds lost their irritability much sooner after the animal's death. He proved this prediction so completely by killing a rabbit instantaneously with a discharge from only $30 \mathrm{sq}$. $\mathrm{ft}$. of coated glass, that he concluded that it was unnecessary to experiment on any other quadrupeds. ${ }^{61}$ According to Van Marum these experiments showed clearly the immediate cause of death in animals and people struck by lightning. Humans and animals could only live when their blood was circulating. Their life would be extinguished as soon as their hearts and large arteries had lost their irritability, for on this depended the ability of these organs to contract ${ }^{62}$ and the resulting circulation of the blood. This meant that humans or animals would always be killed when the lightning passed through the heart and the large arteries connected to it.

These experiments also demonstrated why people and animals were not always killed by lightning. For instance, when the lightning discharge did not pass through the heart and large arteries, it only paralysed the muscle fibres through which it passed, and as the circulation of the blood continued, the person would remain alive. A lightning discharge would also cause instant death when it passed through the spinal cord, but Van Marum knew of no cases where this had happened. He suspected that in all cases where the spinal cord was struck, part of the discharge would in fact pass along the arteries which were in contact with the spinal cord, and in this way destroy their irritability. He thought that the only case in which the electrical discharge or lightning flash would kill the animal without destroying the

${ }^{60}$ Ibid., pp. 231-33.

61 Ibid., pp. 235-37.

62 Ibid., p. 239. 

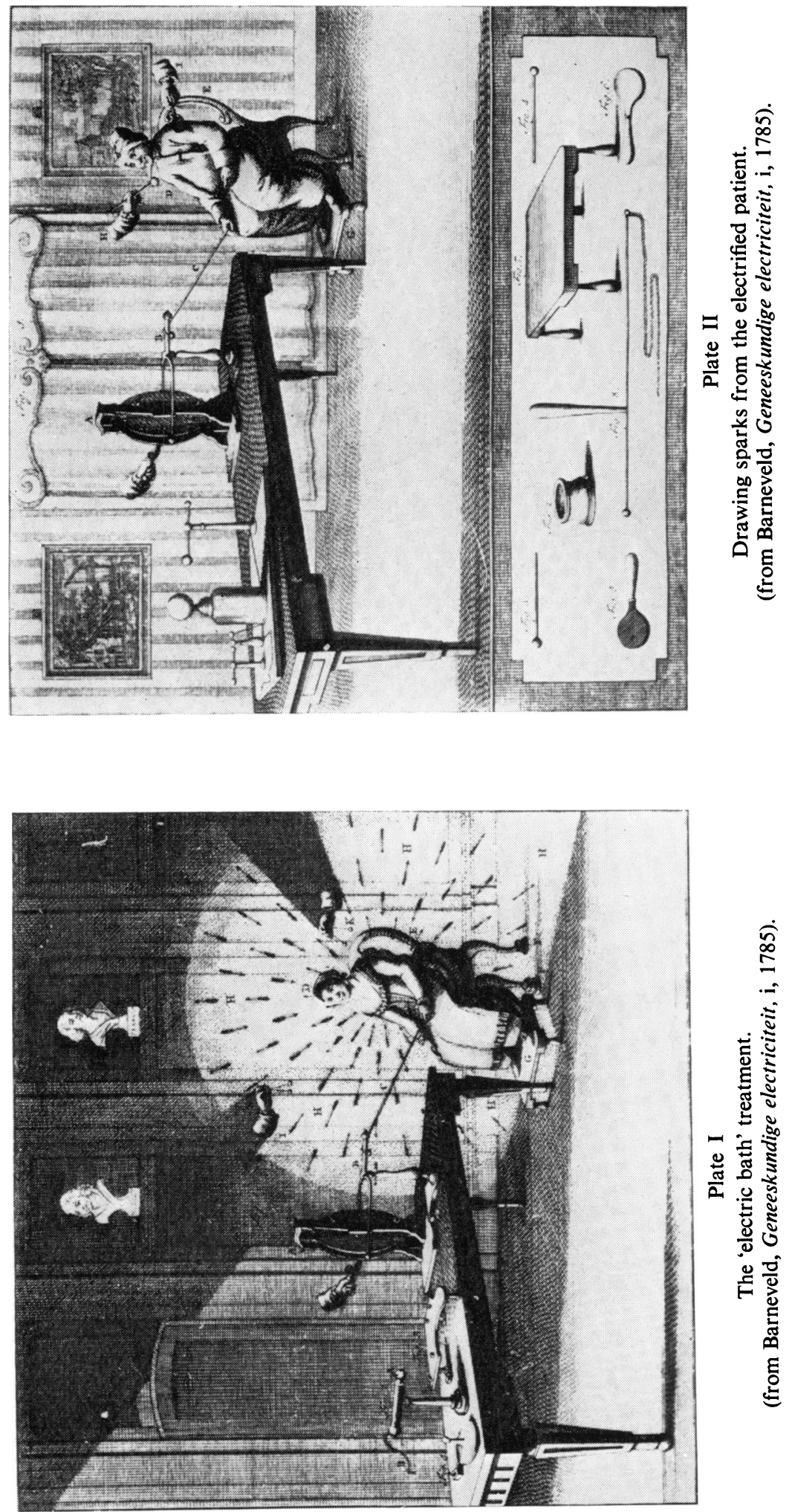

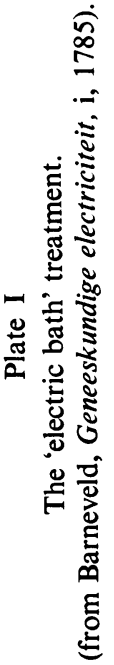




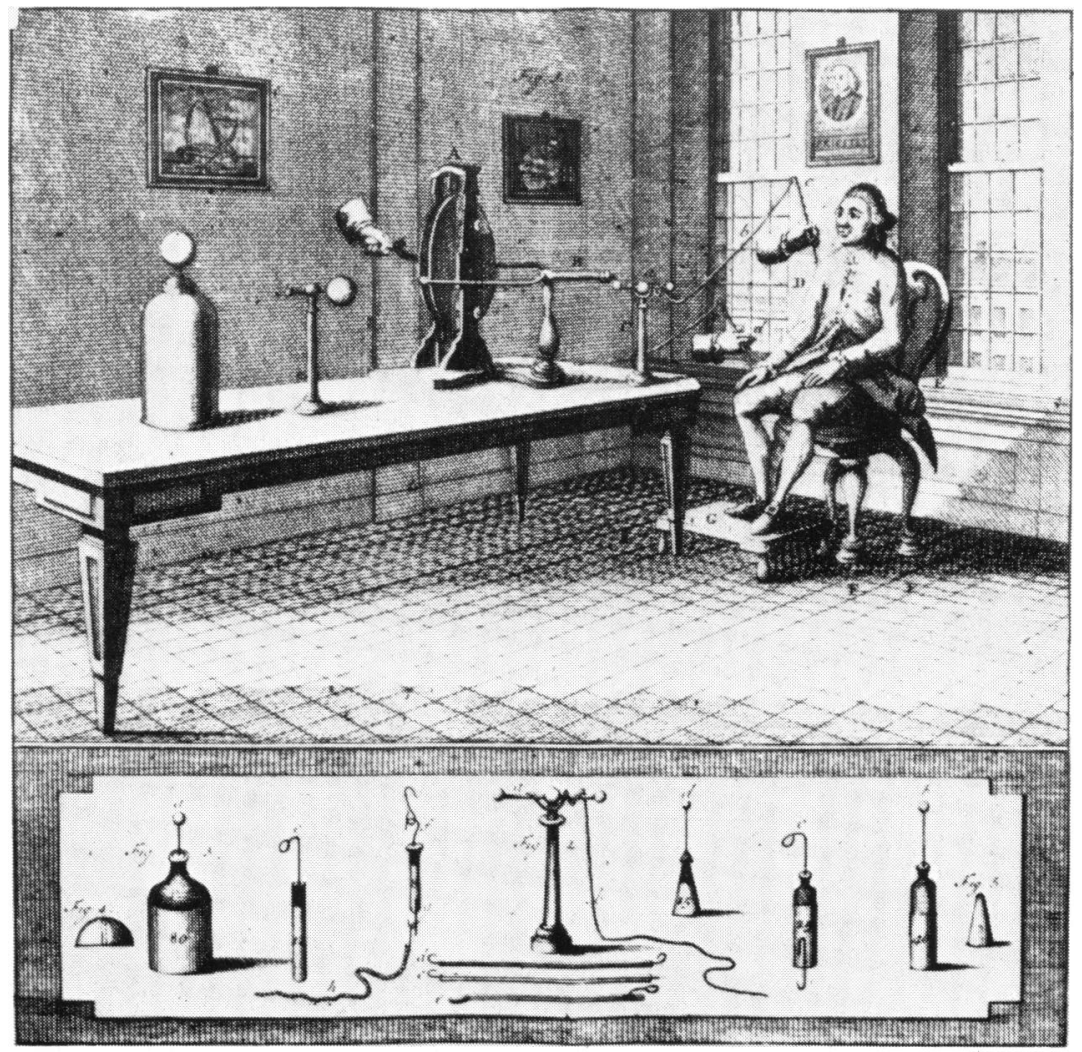

Plate III

Passing an electric discharge through a part of the patient's body. (from Barneveld, Geneeskundige electriciteit, i, 1785). 
irritability of the heart and large arteries was when it passed through the brain. However, a lightning discharge would only very seldom take this route, and a battery discharge would never do so unless it was specifically made to pass through the head. ${ }^{63}$

\section{EXPERIMENTS ON PLANT IRRITABILITY}

These ideas on the irritability of muscle fibres had a great influence on Van Marum's work on the physiology of plants, and his hypothesis of the existence of irritability in plants was completely based on an analogous argument. The analogy he made was between the vessels (sapbuizen) of the plant and the blood vessels or arteries (bloedvaaten) of the animal. In both cases, when a cut was made through these vessels, liquids would flow out. Since, according to Van Marum, the flowing of the blood from such a cut was caused by the contraction of the blood vessels, the juices flowing from a cut stem of a plant must be caused by the contraction of its vessels. ${ }^{64}$ Already in 1773 he had put forward this idea in his thesis on plant physiology, entitled, Dissertatio philosophica inauguralis, de motu fluidorum in plantis, experimentis et observationibus indagato. ${ }^{65}$ In the same year he also thought that he had found a proof for this hypothesis when experiments on the antherae (pollen filaments) of certain plants seemed to indicate a certain amount of irritability in these parts. ${ }^{66} \mathrm{He}$ was rather pleased when Bonnet in 1781 published similar views in his 'Contemplation de la nature'. ${ }^{67}$ Bonnet wrote that he thought the movement of the juices in plants to be due to the contraction of its vessels, the action of its air tubes, and the evaporation through the leaves.

According to Van Marum, the difficulty was to determine whether the contraction of both the vessels in plants and the blood vessels in animals had a common origin. In animals, the irritability of the muscle fibres, that is, their ability to contract when stimulated, was known to cause the contraction of the blood-vessels or arteries, for these were surrounded by a coat made up of muscle fibres. The difficulty was to determine whether the vessels of plants were also surrounded by such a structure, for these vessels were extremely fine, and therefore could not be seen properly even in the best microscopes of his days. When still in Groningen, he had spent many hours dissecting freshwater plants as these were considered to have the largest vessels, but even the structure of these he could not determine by optical means. ${ }^{68}$

In 1791, Van Marum carried this analogous argument a step further. If animal irritability could be destroyed by means of a powerful electrical current which paralysed the muscle fibres, and if the irritability of plants was caused by a similar structure, then this, too, could be destroyed by the same electrical current. If plant

es Ibid., p. 239.

"4 Ibid., p. 69.

ob With this thesis Van Marum graduated in the natural sciences at Groningen University on the 7 August 1773. His experiments on the antherae referred to in Van Marum, op. cit., p. 73 (footnote), were reported in his thesis with which he graduated at the same university a fortnight later (i.e. on 21 August 1773) in the medical sciences. It was entitled Dissertatio botanico-medico inauguralis, disquisitio quo usque motus fluidorum, et caeterae quaedam animalium et plantarum functiones consentiunt. G6 Van Marum, op. cit., p. 73 (footnote).

67 Van Marum is here referring to vol. iv of C. Bonnet, Oeuvres d'histoire naturelle et de philosophie, 8 vols., Neuchâtel, 1779-1783, which is entitled, 'Contemplation de la Nature', 1781, p. 199.

Charles Bonnet (1720-1793), Swiss naturalist and philosopher.

s8 Van Marum, op. cit., (n. 48), pp. 73-75. 


\section{W. D. Hackmann}

irritability could be destroyed by this means, and if the movement of its juices in its vessels arose from this irritability, then, when the electrical current destroyed its irritability, the juices would no longer be able to move in the plant. Thus, when its stem was cut immediately after a discharge had passed through it, no liquid would flow from it. In the summer of 1791 he put this hypothesis to the test. He took different Euphorbias (spurges) from which flowed a milky white fluid when cut. $\mathrm{He}$ passed electrical currents of between 20 to 30 seconds duration through specimens of the Euphorbia lathyris, Euphorbia campestris, Euphorbia cyparissias, and the Euphorbia peplus, and noticed that on cutting the stems of these plants, no liquid flowed from them. He repeated this experiment with branches of a fig tree, and again found that after he had only passed a current through these for a quarter of a minute, no fluid flowed from the freshly made cuts, except for a few drops which appeared when he pressed the branches between his fingers. This showed that the vessels of these branches had not been emptied of their fluid by the current passing through them. What had happened was that these vessels had lost their ability to contract. S. J. Geuns from Utrecht and C. P. Schacht from Harderwijk were present at these experiments. Both were professors of medicine and botany (kruidkunde). ${ }^{69}$ To ensure that these experiments were not distorted by the vast amount of electrical power produced by Teyler's large machine, he repeated some of them with a much smaller machine, but the outcome remained unchanged.

Van Marum also tried to discover the effect a discharge from a Leyden battery might have on plants. He found that when he passed the discharge produced by a 15 sq. ft. battery charged to such a level that it would not split the stem of the plant, the plant had again lost all signs of irritability. He thought that these experiments adequately proved his hypothesis that the movement of the juices in plants was produced by the same mechanism which caused the circulation of blood in animals. According to him, scholars who argued against this conclusion by suggesting that irritability in the case of plants might be caused by a totally different structure, and that plants might not have muscle fibres around their vessels, were in fact denying the essential 'simplicity of nature': 'a matter which was totally opposite to that unity or similarity of causes which we find in nature to be the underlying cause of similar phenomena.' 70

Immediately after his experiments on the Euphorbias in January 1791, Van Marum wrote to Ingenhousz about his results, and this letter was published in the Journal de Physique of the same year. ${ }^{71}$ One of the major results of this letter was that it led to the correspondence between Jean Senebier of Geneva, who was very interested in plant physiology, and Van Marum. This correspondence lasted from 1791 to 1806.

6o Steven Jan van Geuns (1767-1796), professor of medicine and pharmacology at Utrecht. After his death, his father Matthias van Geuns (1735-1817), professor of medicine at Harderwijk and from 1791 at Utrecht, tried unsuccessfully to convince Van Marum to take up his son's post.

C. P. Schacht (1767-1800), botanist living in Harderwijk and extremely interested in physiology. In 1792 he published some galvanic experiments in an 'open letter' addressed to Van Marum. See his 'Brief aan Van Marum behelzende eenige nagevolgde proefnemingen omtrent de dierlijke electriciteit', Alg. Konst- en Letterbode, 1792, 2, $201 \mathrm{~b}$.

${ }^{70}$ Van Marum, op. cit., (n. 48), p. 85.

${ }^{71}$ M. van Marum, 'Seconde lettre à Jean Ingenhousz, contenant quelques expériences et des considerations sur l'action des vaisseaux des plantes qui produit l'ascension et le mouvement de leur seve', J. Physique, 1792, 41, 214-20. 
Senebier already knew about Van Marum's work on plant physiology, for after an extract of Van Marum's 1773 dissertation on this topic appeared in the Journal de Scavans, Senebier asked Van Swinden in 1780 to obtain the complete thesis for him to read. In his five-volume book on plant physiology published in 1800 , Senebier included many of Van Marum's experiments on the irritability of plants. He wrote of Van Marum's work, '. . . aussi je regarde les expériences de Van Marum, comme l'argument le plus favourable pour l'irritabilité des végétaux, et comme étant le seul contre lequel je n'ai rien à opposer.' He also said about Van Marum in volume three of this work, 'Je joindrai ici quelques expériences de Van Marum bien connu par ceux qui recherchent les expériences pensées avec génie et exécutées avec précision.'72 In his book Aphorism aus der chemischen Physiologie der Pflanzen, Alexander von Humboldt also referred to some of Van Marum's experiments on plant physiology, and called him a man 'durch dem die Pflanzenphysiologie so unentlich gewonnen hat.' ${ }^{\prime 3}$

\section{CONCLUSION}

The first point that this account of Van Marum's medico-electrical and botanicoelectrical researches illustrates is a rather interesting philosophical one. This is the manner in which he invoked the principle of the simplicity of nature in his analogous argument that the structure of the plant vessels and animal arteries must be similar, as the property of irritability could be extinguished in both by means of an electrical discharge. Van Marum must have been encouraged in his use of the analogous argument by the famous success of Franklin, who, by means of an analogy, hypothesized the essential similarity between artificially produced electricity and the lightning flash, and then 'proved' it by means of the 'electrical kite' experiment. However, we now know that the movement of plant juices is brought about by a totally different mechanism to that which causes the circulation of blood in animals. The latter is indeed controlled by the contraction of the heart and by the parasympathetic and sypathetic nervous systems which can dilate and contract blood vessels, and will do so under certain conditions. The movement of fluids in plants is not controlled by any such mechanism. In this case it is primarily caused by the evaporation of the fluids from the leaf's surface and is assisted by the capillary movement of these fluids in the extremely fine vessels of the plant. No doubt Van Marum's electrical discharges did cause contractions or convulsions in the parts of the body through which they passed. In the case of plants, Van Marum's electrical current passing through the plant most probably destroyed its root pressure by puncturing the semi-permeable membrane of the pericycle in the root, and consequently the fluids would no longer flow from the cut stem. This oversimplified use of the principle of the simplicity of nature and the analogous argument was one of

72 Forbes, op. cit., i, pp. 10f. Jean Senebier (1742-1809), professor of chemistry at Geneva.

${ }^{78}$ F. H. A. von Humboldt, Aphorism aus der chemischen Physiologie der Pflanzen, Leipzig, 1794, p. 38. This work was translated from the Latin into German by G. Fischer. See also Forbes, op. cit., i, p. II. I have not discussed a small number of botanico-electrical experiments described by Van Marum in chapter VII of the 1795 volume of the Verh. Teyler's Genoot., as these have no bearing on his main work in this field. Van Marum did not consider these experiments very important as, on the whole, the results were not very clear cut. These include experiments on the rate of evaporation of plants, on the possible effects electrification may have on sensitive plants, and on how young trees were affected by discharges from his large battery. 


\section{W. D. Hackmann}

the main weaknesses in the experimental approach of the eighteenth-century 'experimentalist'.

Secondly, this account shows that Van Marum was an extremely careful experimenter, who attempted to control all the factors he could think of, and, furthermore, that he trusted his own experimental results enough to discard well established theories even when based on experiment. His independence of mind is also demonstrated by the fact that, unlike most of his eighteenth-century contemporaries, he had little belief in the curative power of electricity. Incidentally, it is worth noting, that nowhere in this period is the use of electricity as a means of stimulating and exercising muscles mentioned, ${ }^{74}$ but only its use as a cure for disorders ranging from hysteria to colic pains. Van Marum's medico-electrical experiments were of no great influence on his contemporaries; the accumulated 'evidence' of the supposed influence of electricity on the body was too vast to be overthrown by the work of a single man, and most physicians in Holland and elsewhere blithely continued to use electricity as a major curative agent for many years to come. We have seen that his work on the similarity of the structure of plant vessels and arteries, and on the effect of lightning on irritability became better known, and was praised by such scholars as Senebier and Von Humboldt. However, this work would have little influence on modern plant physiology, since his over simplified analogy had led Van Marum to a totally incorrect conclusion about the structure of plant vessels. His ideas on animal irritability are still more or less in harmony with modern research.

Finally, a survey of the Dutch medico-electrical researches of the eighteenth century highlights another interesting point, and that is the ease with which a subject can become acceptable, not because it has a strong theoretical background, but simply because a large amount is written about it. Medical electricity as a form of treatment was extremely fashionable. Some of the more astute administering it realized that a high-sounding title and impressive-looking equipment also assisted in the cures. Reading the case histories of patients cured by electricity, one is at once struck by the hysterical behaviour of many of these patients during treatment. However, a vicious circle was established. Cures gave credence to the treatment, which in turn led to more articles and the writing up of case histories. This led to more physicians attempting this form of treatment, which led to more hysterical patients being cured, leading to an even greater volume of articles and case histories, and a scholar superficially surveying the large amount of material written about medical electricity by the beginning of the nineteenth century, would think it to be quite respectable. A sceptic may draw some sort of parallel between the twentieth century's work on E.C.T. and the work on medical electricity in the eighteenth century. This would not be completely fair, however, for the modern theories are at least somewhat more sophisticated, and perhaps have a bigger chance of proving successful than the eighteenth-century theories based on the 'principium vitale'.

\section{ACKNOWLEDGEMENTS}

I wish to thank both Dr. W. L. Parry-Jones, University Lecturer of Psychiatry, Oxford, and Mr. G. L'E. Turner of the Museum of the History of Science, Oxford, for their valuable comments and suggestions.

"Except by Jallabert in 1747, whose work was largely ignored. See note 15. 